\title{
Dative by Genitive Replacement in the Greek Language of the Papyri: A Diachronic Account of Case Semantics*
}

\author{
Joanne Vera Stolk \\ Department of Philosophy, Classics, History of Art and Ideas, \\ University of Oslo, Norway \\ j.v.stolk@ifikk.uio.no
}

\begin{abstract}
Semantic analysis of the prenominal first person singular genitive pronoun ( $\mu \circ v)$ in the Greek of the documentary papyri shows that the pronoun is typically found in the position between a verbal form and an alienable possessum which functions as the patient of the predicate. When the event expressed by the predicate is patient-affecting, the possessor is indirectly also affected. Hence the semantic role of this affected alienable possessor might be interpreted as a benefactive or malefactive in genitive possession constructions. By semantic extension the meaning of the genitive case in this position is extended into goal-oriented roles, such as addressee and recipient, which are commonly denoted by the dative case in Ancient Greek. The semantic similarity of the genitive and dative cases in these constructions might have provided the basis for the merger of the cases in the Greek language.
\end{abstract}

\section{Keywords}

Greek papyrology - cognitive linguistics - dative - genitive - pronouns - possession construction - case syncretism - affectedness - semantic extension

* This article was presented at the 21st International Conference on Historical Linguistics, Oslo,

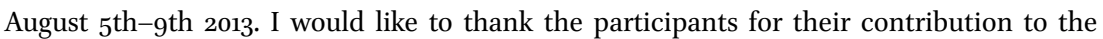
discussion as well as Anastasia Maravela, Mark Janse, Trevor Evans, Eirik Welo, Dag Haug and two anonymous reviewers for their useful comments on earlier drafts of this article. 
The topic of this article is the gradual replacement of the dative by the genitive case in the Greek language of the papyri found in Egypt. ${ }^{1}$ Two observations have been made about this diachronic change. Firstly, the interchange between dative and genitive case endings is found with personal pronouns in the papyri (Humbert 1930:166-171). ${ }^{2}$ Secondly, Humbert (1930:171) noticed that both interpretations 'buy my part of the olive grove' and 'buy me part of the olive grove' are possible in example (1). ${ }^{3}$

\author{
(1) àróparóv \\ Mov $\mid \tau \dot{~}$

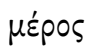 \\ buy-2SG.AOR.IMP.ACT 1SG.GEN the-ACC.SG part-ACC.SG

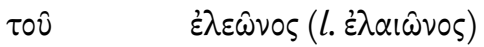 \\ the-GEN.SG olive grove-GEN.SG \\ BGU II 602, 5-6 (II CE $)^{4}$
}

1 Greek was used in Egypt during the Graeco-Roman-Byzantine period (332 BCE - 641 CE). The main sources for Greek in Egypt are documents written on papyrus and ostraca (potsherds). The linguistic situation in Egypt was pluriform and complex due to varying levels of literacy and bilingualism among the speakers, cf. Bubeník 1989:214-227; Torallas Tovar 2010.

2 Humbert (1930:166): “Tandis que les examples précédents, tires des ostraca, concernent exclusivement les noms propres, la plupart de ceux que fournissent les papyrus se rapportent surtout à une autre catégorie, celle des pronoms personnels." Hence it is generally assumed that the replacement of the dative by the genitive started with pronouns before extending to noun phrases in general (cf. Browning 1983: 37; Horrocks 2010: 180). The confusion of the genitive and dative cases of the first and second person singular pronouns is not likely to be caused by phonological merger (Gignac 1981:215n1) and, therefore, they are most suitable for functional analysis. For the first and second nominal declensions, on the other hand, almost all case endings might be interchanged due to phonological changes during the Roman and Byzantine periods, cf. Gignac (1976:213-214; 111-112; 124-125; 131-132). The main question remains whether interchange in the personal pronouns is indeed more frequent, or at least earlier established, than in nominal forms, as has been claimed previously. As a few individual examples can hardly be decisive in this matter, a systematic study of case interchange in nominal declensions in Greek papyri is highly desirable.

3 Humbert (1930:171) adds to this example of dative substitution: "La substitution n' est pas certain ici, car Souchas pouvait dire à son voisin: 'achète-(moi) $m a$ part de ce que je possède en oliviers.'” Indeed Souchas can also be perceived as the original owner of the olive grove instead of the purchaser (see Bagnall and Cribiore 2006:178).

4 Papyrus editions are cited according to the "Checklist of Editions of Greek, Latin, Demotic and Coptic Papyri, Ostraca and Tablets", at http://library.duke.edu/rubenstein/scriptorium/ papyrus/texts/clist_papyri.html, December 2013. Critical signs are in accordance with the so- 
The overlap of the adnominal genitive possessive pronoun ('my part') and the dative pronoun as verbal complement ('buy me') in this position is commonly taken to be the starting point for the merger of the dative and the genitive cases (Merlier 1931; Horrocks 2007:628-629; 2010:180; Gianollo 2010). Many of the interchanges in the papyri from the Roman period are indeed found in the position in which the pronoun might belong to the preceding verb phrase (VP) or the following noun/determiner phrase (DP). Because of the predominant verb-initial word order in Koine Greek, the 'second' postverbal position became the standard position for object clitics in accordance with Wackernagel's Law (Janse 1993; Taylor 2002; Horrocks 2007:621-623). ${ }^{5}$ Hence the postverbal position is expected to be the standard position for the dative object clitic pronoun. Regarding the genitive possessive clitic pronoun, the postnominal position is standard in Koine Greek (Breuillot 1997; Janse 2002:379-383), while the prenominal 'second' position is less common for genitive pronouns modifying a noun (Janse 1993). In the papyri, the first person genitive clitic pronoun ( $\mu \circ v)$ mostly appears in postnominal position (NG), but it also occurs in prenominal (GN) position coinciding with the object clitic pronoun (see table 1 , section 4).

Even though the coinciding of the dative and the genitive pronouns in this position might be in accordance with Wackernagel's Law and the resulting process of reanalysis of the genitive as the verbal argument could be accounted for syntactically (Cooper and Georgala 2012), this does not yield a semantic explanation for the overlap between preposed genitive pronouns and dative object pronouns. An interesting explanation has been provided by Gianollo (2010) for New Testament Greek, but this has not been applied to the Greek language of the papyri. Therefore, I will examine the meaning of the genitive

called “Leidener Klammersystem", cf. B.A. van Groningen, "Project d' unification des systèmes de signes critiques," Chronique d'Égypte 7 (1932) 262-269. The Greek text is taken from the Papyrological Navigator (PN, www.papyri.info), the date from the Heidelberger Gesamtverzeichnis der griechischen Papyrusurkunden Ägyptens (HGV, http://www.rzuser.uni-heidelberg .de/ gvo/) and both are checked against the editio princeps (ed.pr.) and Berichtigungsliste $(B L)$. Translations are my own, but they are based on the translation of the edition if available. Notes from the critical apparatus are inserted between brackets in the Greek text: 'corr. ex.' provides the form from which the text is corrected on the papyrus and 'l.' signals a correction by the modern editor, usually in comparison with Classical Greek or based on parallel texts.

5 For a discussion of the principles of Wackernagel's Law see Clackson (2007:168-171); for the possible impact of bilingualism on clitic position see Janse (2002:379-383). 
pronoun in Greek papyri in this article in order to identify any semantic ambiguity between the genitive and the dative pronoun. I will show that the start of genitive and dative interchange might be found in the semantic extension of the genitive as possessor into the role of malefactive/benefactive in situations in which the possessor is affected by the event described by the predicate. From the role of the malefactive/benefactive the meaning of the genitive case could have been extended further into goal-oriented roles such as addressee and recipient, which are commonly denoted by the dative case in Ancient Greek.

This article is organised as follows: section 2 deals with previous approaches to this topic, section 3 provides the theoretical background, while section 4 shows the results from quantitative analysis. Section 5 explores the special meaning of the genitive pronoun in prenominal position in order to determine the first stage of the merger, while section 6 attempts to answer the question of how this meaning of the genitive was further extended into the dative semantic domain. A summary of the findings can be found in section 7 .

\section{$2 \quad$ Previous Research}

The study of dative-genitive syncretism in Greek has a long history and several explanations have been suggested that could provide an interesting starting point for the examination of the genitive functions in the papyri. Although the study of Humbert (1930) is the only comprehensive work on the replacement of the dative to date, it does not provide a systematic explanation or motivation for the replacement of the dative by the genitive case. The reasons for dative by genitive replacement have been further explored by Hatzidakis (1929) and Merlier (1931). Merlier (1931) examines the relation between the dative and genitive case at both a semantic and syntactic level and provides many examples of possible genitive constructions leading to reanalysis and further extension into dative functions. Most importantly, he shows the overlap in position of the dative complement and the genitive possessive clitic pronoun in Koine Greek as the syntactic basis for reanalysis.

Recently, Gianollo (2010) followed up on the connection between the changes in word order and clitic position and semantic reanalysis of the genitive pronoun. ${ }^{6}$ König and Haspelmath (1998:584-586) following the proposal of

6 See also the presentation by Chiara Gianollo, "How did genitives become datives in Greek", 
Havers (1911:169) suggested that the dativus sympatheticus, which they analyse as an external possession construction, might be taken over by the prenominal genitive possessive in Greek. Gianollo (2010) then examines the properties of the genitives in New Testament Greek and concludes that the distribution of the extraposed genitives indeed overlaps with that of a dative in an external possession construction. Hence, based on the data from the gospel of John, a specialisation of this genitive possessive construction can be seen as the basis for the development of the dative and genitive case merger. This study provides a very useful starting point as a basis for comparison. However, the construction of a dative as external possessor is rare in the papyri and the prenominal genitive pronouns in the papyri do not show the properties which are characteristic for external possession constructions either (see section 5). Therefore, an alternative semantic explanation is required to account for the genitive-dative interchange found in documentary papyri from Egypt.

Horrocks (2007:629) proposes that in the prenominal position "the 'displaced' genitive could then very easily be reinterpreted as performing the same function as an 'ethical' dative or dative of 'advantage/disadvantage', a point of contact which quickly led to the assumption of all dative functions by genitive clitic pronouns". He provides some papyrological examples (Horrocks 2010:180; 2007:628-629), but no further semantic explanation or evidence of how this reanalysis from adnominal genitive possessor to the genitive as benefactive/malefactive or 'ethical dative' verbal complement should have taken place and how it spread to other dative functions. Markopoulos (2010) suggests that a cognitive path connecting the beneficiary/indirect object with the domain of possession might explain the use of the accusative in genitive contexts through the association with the dative case in the replacement of the genitive plural by the accusative plural in Medieval Cypriot Greek. This presupposes a close cognitive relation of the genitive and dative case in earlier stages of the Greek language, such as in the Greek language from the RomanByzantine period.

at DIGS XIII, Diachronic Generative Syntax Conference, University of Pennsylvania, June 5 , 2011, abstract available at http://www.ling.upenn.edu/Events/DIGS13/gianollo. 
The interchange between genitive and dative in the papyri is part of a larger process of dative case syncretism. ${ }^{7}$ The papyri $(300 \mathrm{BCE}-800 \mathrm{CE})$ cover most of the period before the loss of the dative case is found in literary texts. ${ }^{8}$ Barðdal and Kulikov (2009:470) note about the stage preceding syncretism: "case syncretism is typically preceded by a period of variation and alternation between case forms or argument structures, with the source forms being interchangeably employed in some usages with only some minor functional distinctions". A stage of "variation and alternation" seems to be an accurate description of the language in the papyrus documents from the Roman and Byzantine periods. The genitive is occasionally used in dative functions while the dative retains mostly its original (conservative) use, resulting in a certain degree of interchangeability between the genitive and the dative cases. The apparent variation in the written language is of course related to the different reflections of language change in the spoken and written language.

The origins of case loss can often be found in the semantic similarity of the merging constructions at a previous stage (Barðdal and Kulikov 2009). The semantic network set up to explain the synchronic polysemy of cases, such as the correspondences between the meanings of one case form, can be helpful to explain and motivate diachronic semantic changes as well (Nikiforidou 1991). Polysemy among the marker(s) for the roles of the benefactive, recipient, malefactive, possessor and goal is regularly found in various languages (Kittilä and Zúñiga 2010:18-24). A semantic extension of the genitive case from the role of possessor to a goal-oriented role might have been caused by semantic similarity with the dative case in Greek. This semantic similarity could provide part of the explanation for the loss of the dative case.

7 The personal dative is not only replaced by the genitive case, but also by the accusative and

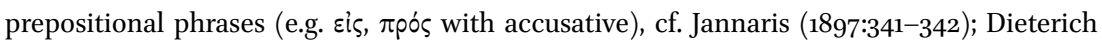
(1898:150-152); Humbert (1930:178-180); Kapsomenakis (1938:24n2); Trapp (1965); Browning (1983:37); Horrocks (2010:284-285). It seems that variation between several of these replacement strategies is indeed attested in documentary papyri, but the chronological, geographical and linguistic distribution of the various substitution patterns needs further study (cf. for example the detailed analysis of the variation between genitive and accusative in Medieval Greek documents by Lendari and Manolessou 2003).

8 The loss of the dative case is thought to have taken place around the eighth to tenth century CE, cf. Humbert (1930:199-200); Browning (1983:37); Horrocks (2010:284-285), although there is no general agreement on the dating. Luraghi (2003:331) for example, assumes an earlier date between the fourth and the eighth centuries CE. The difficulty, of course, lies in the dating of changes in the spoken language based on written documents. 


\subsection{Possession Constructions}

The natural semantic overlap of the genitive and the dative cases lies in the conceptual domain of possession, since both the dative and the genitive case can be used to express possession in Greek. The prototypical concept of possession is characterized by a relationship between two entities, the possessor and the possessum (the thing possessed). The main function of the genitive pronoun is to express the possessor of a following or preceding noun that takes the role of the possessum. A wide range of relations and associations between concepts can be expressed by possession constructions, resulting in abstract or rather vacuous descriptions of the general meaning of this construction (see Heine 1997:2-9). However, there are various semantic and syntactic criteria to further delimit this large category. These criteria will be introduced in this section in order to distinguish the Greek possession constructions that will be discussed in this article.

There are three main syntactic categories of possession constructions that occur with the personal pronoun in Koine Greek: attributive or internal (2), predicative (3) and external possession (4). ${ }^{9}$



the-ACC.PL feet-ACC.PL 1SG.GEN

'my feet'

P.Lond. II $35^{8}$ (p. 171), 11-12 (150-154 CE)

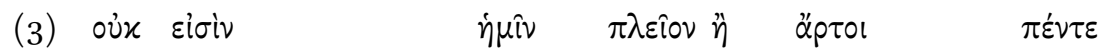

NEG be-3PL.PRS.IND.ACT 1PL.DAT more than bread-NOM.PL five

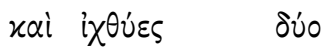

and fish-NOM.PL two

'we have no more than five loaves of bread and two fish'

NT, LUKE 9.13

9 Already during the Ptolemaic period the usage of the possessive adjectival pronoun becomes marked and diminishes in favour of the genitive of the personal pronoun in attributive possession (Mayser 1934: 64-68), cf. P.Cair.Zen. III 59341, v (b) 6 (after 06.06.247

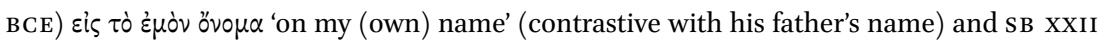

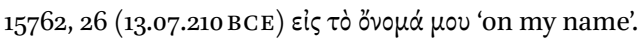




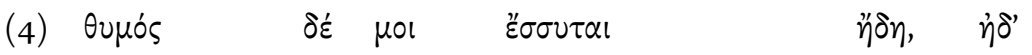 spirit-NOM.SG and 1SG.DAT drive-3SG.PRS.IND.MID already and

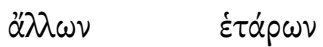
other-GEN.PL comrades-GEN.PL

'for my spirit is now eager to be gone, and the spirit of my comrades' Hom.Od. 10.484-485 (from GIANOLLO 2010:112) ${ }^{10}$

In an attributive possession construction the possessor is encoded by a (prenominal or postnominal) genitive, whereas the possessor in a predicative possession construction is usually expressed by the dative case. The dative pred-

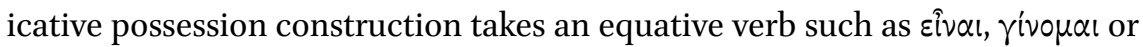
v $\pi \alpha{ }^{\prime} \chi \omega$. This construction can be highly similar to the genitive possessive pro-

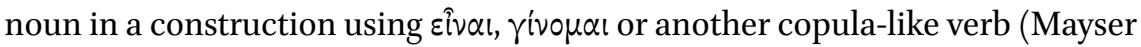
1934:188-189; 269-270). The similarity in form and meaning of the genitive and the dative in these possession constructions was already present in Classical Greek (cf. Benvenuto and Pompeo 2012).

Another possession construction in Greek in which the dative takes a possessor role is the so-called external possession construction (EPC). It differs from the internal (attributive) possession construction in that the "possessorpossessum relation is expressed by coding the possessor $(\mathrm{PR})$ as core grammatical relation of the verb and in a constituent separate from that which contains the possessum (PM)" (Payne and Barshi 1999:3). However, the construction does not coincide with predicative possession either, since "the possessorpossessum relationship cannot reside in a possessive lexical predicate such as have, own or be located at and the lexical verb root does not in any other way have a PR within its core argument frame" (ibid.). It has been suggested that the dative in an external possession construction, also called the dativus sympatheticus, might have been replaced by the genitive case in Koine Greek (Havers 1911:169; König and Haspelmath 1998:584-586; Gianollo 2010). Already in Classical Greek, but especially in New Testament Greek, there are examples in which the genitive as a possessor occupies either the first position of the noun phrase or the position immediately prior to the noun phrase which contains the possessum (5) and examples where it occupies a position altogether outside of the noun phrase containing the possessum (6).

10 In this construction the dative (of the pronoun) and the genitive (of the full noun phrase) seem to alternate (Gianollo 2010:112). 


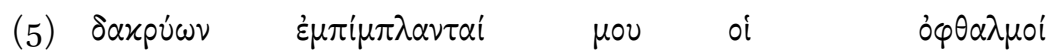
tears-GEN.PL fill-3PL.PRS.IND.MP 1SG.GEN the-NOM.PL eye-NOM.PL 'my eyes are filled with tears'

PLATO, Ion 535 C 6 (from GIANOLLO 2010:112)

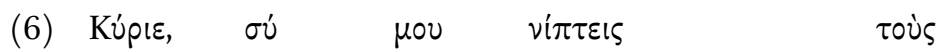

Lord-VOC 2SG.NOM 1SG.GEN wash-3SG.PRS.IND.ACT the-ACC.PL $\pi$ ó $\alpha \varsigma$

feet-ACC.PL

'Lord, do you wash my feet?'

NT, JOHN 13.6 (from MERLIER 1931:219)

The occurrence of a genitive possessor detached from the possessum (6) is rare in the papyri. However, by being adjacent to the noun (5) the genitive prenominal possessive might not be separately construed from the constituent that contains the PM. It is therefore important to define other properties of the dative as external possessor in order to determine to what extent the prenominal genitive in Greek papyri meets the requirements of an EPC. Several factors are relevant for the distribution of the external possession construction (see Fried 1999; Payne and Barshi 1999:3-29; Haspelmath 1999:110-115). I will use the following criteria for the analysis of the prenominal genitive:

a. The Syntactic Relations Hierarchy:

An EPC is favoured if the syntactic relation of the possessum is: prepositional phrase $<$ direct object $<$ unaccusative subject $<$ unergative subject $<$ transitive subject

b. The Animacy Hierarchy:

An EPC is favoured if the possessor is: 1 st $/ 2 n d$ p. pronoun $<3 r d$ p. pronoun $<$ proper noun $<$ other animate $<$ inanimate

c. The Inalienability Hierarchy:

An EPC is favoured if the possessum is: body part $<$ inherent attribute $<$ garment $<$ kinship term $<$ close alienable entities $<$ distant alienable entities

d. The Situation Hierarchy:

An EPC is favoured if the possessor is thought of as being (positively or negatively) affected by the event described by the predicate, i.e. if the predicate is: patient affecting $<$ dynamic non-affective $<$ stative. 


\subsection{Ditransitive Constructions}

The semantic extension of the genitive case into dative functions can be found in constructions in which the genitive pronoun functions as the recipient-like argument of a ditransitive construction. I define a ditransitive construction as "a construction consisting of a (ditransitive) verb, an agent argument (A), a recipient-like argument (R) and a theme argument (T)", following the typological study of polysemy patterns in ditransitive constructions by Malchukov et al. (2010). Several relevant constructions fit this definition, such as the patientbenefactive construction, the theme-goal construction or the theme-recipient construction, depending on the lexical semantic verb class and the semantic roles of the participants (Malchukov et al. 2010:48-54).

Cross-linguistically, also the animate source construction can be connected with the ditransitive theme-recipient construction (Newman 1996:115-118). The data from the papyri include two types of source constructions: the malefactive source construction with verbs for 'take' and the more neutral themesource construction with verbs for 'receive'. The source is in both constructions denoted by the genitive case. The malefactive source construction can be seen as the equivalent of the benefactive goal-oriented constructions ('buy for'), while the theme-source construction resembles the theme-goal construction with verbs such as 'send' and 'bring'. The nature of the recipient-like argument in a ditransitive construction might therefore provide another explanation for the functional overlap between the dative and the genitive cases.

\section{$4 \quad$ Data and Quantitative Analysis}

The empirical basis for this study is a collection of all attestations of the genitive first singular pronoun ( $\mu 0 v)$ from the Ptolemaic $(300-1 \mathrm{BCE})$, Roman $(1-400 \mathrm{CE})$ and Byzantine (401-80o CE) periods, ${ }^{11}$ gathered by means of the Papyrologi-

11 A linguistic division of Koine Greek in three stages, Early (III-I BCE), Middle (I-III CE) and Late (IV-VI), has been proposed by John Lee, cf. Evans and Obbink (2010:11-12). In this article a historical division is made between the Ptolemaic (III-I BCE), Roman (IIV CE) and Byzantine (V-VIII CE) periods. The main reason for taking $400 \mathrm{CE}$ as the break between Roman and Byzantine periods instead of the reign of Diocletian (284-305 CE), is the fact that among papyri without a precise date there are many papyri that are palaeographically dated to the III-IV century and very few to the IV-V. However, the linguistic division between the third and fourth century is confirmed in chronological analysis; cf. section 6 and 7 . 
TABLE 1 Position of the genitive pronoun $\mu$ ov relative to the position of the noun/verb

\begin{tabular}{|c|c|c|c|c|c|c|c|c|c|c|c|c|}
\hline & \multicolumn{2}{|c|}{ NG } & \multicolumn{2}{|c|}{ AGN } & \multicolumn{2}{|c|}{ GN } & \multicolumn{2}{|c|}{ VG/PG } & \multicolumn{2}{|c|}{ Uncertain } & \multicolumn{2}{|c|}{ Total } \\
\hline & $\mathbf{N}$ & $\%$ & $\mathbf{N}$ & $\%$ & $\mathbf{N}$ & $\%$ & $\mathbf{N}$ & $\%$ & $\mathbf{N}$ & $\%$ & $\mathbf{N}$ & $\%$ \\
\hline Ptol. & 264 & 34 & 57 & 7 & 83 & 11 & 220 & 28 & $15^{2}$ & 20 & 776 & 100 \\
\hline Rom. & 2904 & 57 & 607 & 12 & 260 & 5 & 337 & 7 & 986 & 19 & 5094 & 100 \\
\hline Byz. & 835 & 45 & 590 & 32 & 39 & 2 & 68 & 3 & 331 & 18 & 1863 & 100 \\
\hline
\end{tabular}

cal Navigator $(P N) .{ }^{12}$ This corpus includes all published documentary papyri and ostraca written in the Greek language, mostly found in Egypt. All first person genitive clitic pronouns were categorized based on the order of the constituents. ${ }^{13}$ Table 1 shows the results of this categorisation. ${ }^{14}$

The word order of the constituents in the noun phrase (GN or NG) is likely to be governed by information structure requirements in Classical Greek and this might explain part of the variation in the constructions in the New Testament

12 I carried out a search for \# $\mu$ ou\# in all Greek texts in the Papyrological Navigator (www .papyri.info), December 2012. Only the pronouns displayed among the results by the $P N$ were analysed; this means that in case there are more occurrences in one document, only the first three or four are taken into account. This makes the amount of results manageable without compromising the variety of text types or the time frame. Unfortunately, the $P N$ does not (yet) present the total number of attestations of a searched form. This makes it is difficult to estimate the coverage of the chosen approach.

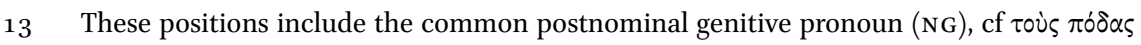
$\mu$ ov 'my feet' (2), and the construction of a DP containing an adjective followed by a

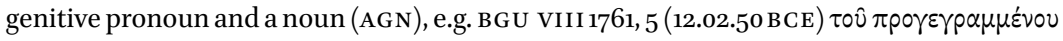

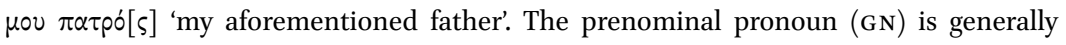
preceded by a (finite) verb form (VGN) and the phrasal genitive is constructed with a verb (VG) or preposition (PG) without the presence of a noun which could function as a possessum (see resp. 4.1 and 4.2). The genitive pronoun is occasionally found between the article and the noun (cf. Breuillot 1997), in the Roman period once and in the Byzantine period 8 times, but these cases are left out in table 1 . The category 'Uncertain' counts the situations in which the state of the papyrus does not allow for proper analysis, i.e. in or next to a lacuna, or due to uncertain reading.

14 The hypothesis can be rejected that the results in this table were generated by chance (Chi-square $=999.82,8$ degrees of freedom, $\mathrm{p}<2.2 \mathrm{e}-16)$. With 2 degrees of freedom Cramer's V $=0.25$ can be considered a medium effect size. The standardized residuals show that the values in the category 'Uncertain' for all periods and the ' $\mathrm{NG}$ ' in the Roman period hardly contribute to this chi-square value, the other categories are significant. 
(cf. Gianollo 2010:121) and in the papyri. ${ }^{15}$ However, through the increasing fixation of the word order in post-Classical Greek, the pragmatic variation between the GN and NG word order is replaced by a generalized NG word order for possessive pronouns, as can be observed in table 1 by the decrease in the $\mathrm{GN}$ word order in the papyri from the Roman and Byzantine period compared to the Ptolemaic period. Even though the categories GN and VG are declining in frequency, it is in those constructions that the overlap between the dative and the genitive cases is found.

\subsection{Prenominal Genitive Constructions (GN)}

The prenominal genitive pronoun (GN) appears in $97 \%$ of the cases directly after a verbal form. This confirms the structural overlap between the prenominal genitive possessive and a dative pronoun as verbal complement. After the syntactic classification, all search results were analysed based on the form and lexical semantic verb class of the preceding verb and the possible semantic roles of the genitive pronoun. In accordance with the position adjacent to a noun, the prenominal genitive pronoun can almost always be regarded an adnominal genitive possessor. However, for some of these examples, the genitive pronoun can also be understood as a denoting source or a dative-like function, depending on the context and lexical semantic verb class. The role of source is here understood as 'the entity from which something moves', cf. 3.2. Both examples of the malefactive source construction with verbs for 'take' (7) and the more neutral theme-source construction with verbs for 'receive' (8) were found amongst these prenominal genitive possessors.

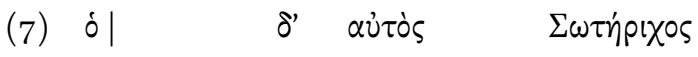

the-NOM.SG and DET.NOM.SG Soterichos-NOM.SG

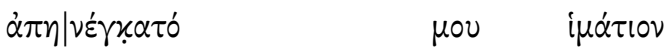

take.away-3SG.AOR.IND.MID 1SG.GEN cloak-ACC.SG 'and Soterichos himself took my cloak away (= from me)'

P.Col. VIII 209, 27-29 (11.10.3CE)

15 E.g. the preposed position of the pronoun could represent an emphasis on the possessive

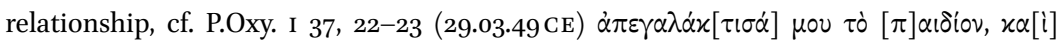

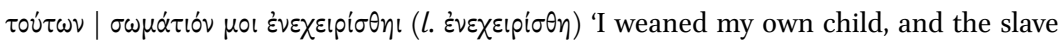
child belonging to these people was placed in my charge'. 


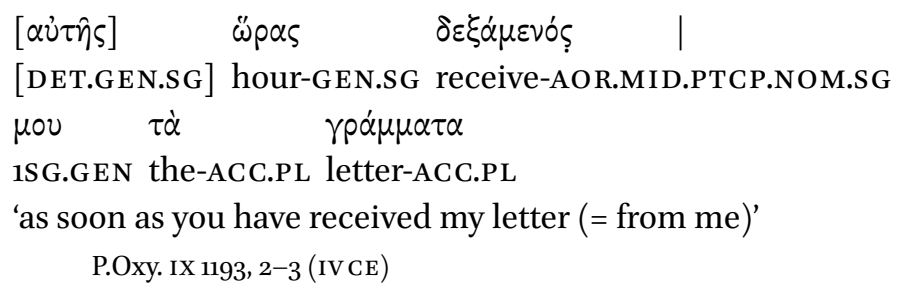

In the dative-like function, the prenominal genitive possessive pronoun can be interpreted as the recipient-like argument of a goal-oriented ditransitive construction based on the context, such as the benefactive possessor in (9).

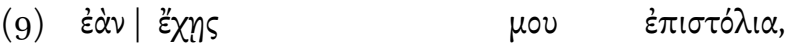 if have-2SG.PRS.SBJV.ACT 1SG.GEN letter-ACC.PL $\pi \varepsilon \dot{\varepsilon} \mid \psi \circ \mathrm{H} \quad \mu \mathrm{Ol}$ send-2SG.AOR.IMP.ACT 1SG.DAT 'if you have my letters (= for me), send (them) to me' O.Claud. II 252, 4-6 (mid II CE)

To show also these 'secondary' semantic interpretations, I distinguish the following five main construction types of the prenominal possessive pronoun: (i) genitive absolute construction (GenAbs), (ii) possession constructions (comprising all three syntactic possession constructions mentioned in section 3.1, but not the genitives that can also be taken to denote source or dative-like semantic roles), (iii) the genitive source construction, cf. (7)-(8), (iv) constructions in which the genitive takes a dative-like function, $\mathrm{cf}$. (9), and (v) the category 'other' containing any remaining constructions. ${ }^{16}$ The frequencies of these construction types are shown in table $2 .{ }^{17}$

16 The common denominator of the remaining constructions is the absence of a verb directly preceding the prenominal genitive pronoun. These examples are few, but interesting because they sometimes show the genitive in extraposed position, e.g. in P.Lond. VII 1976,

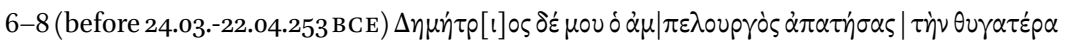
'but Demetrios the vine-dresser having deceived my daughter', the genitive pronoun

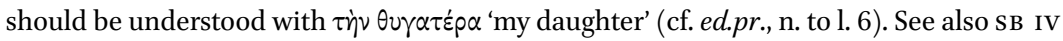

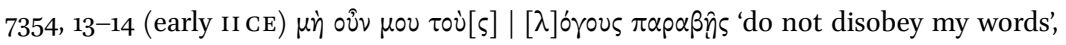
where the genitive pronoun is preposed while the verb is in final position. The special word order of these examples might denote the possessor being mentally or emotionally affected by the event, cf. section 5 .

17 The hypothesis can be rejected that the results in this table were generated by chance (Chi-square $=31.82,8$ degrees of freedom, $\mathrm{p}=0,0001)$, although caution is required since 
TABLE 2 Constructions containing the prenominal (GN) genitive pronoun $\mu$ ov

\begin{tabular}{|c|c|c|c|c|c|c|c|c|c|c|c|c|}
\hline & \multicolumn{2}{|c|}{ GenAbs } & \multicolumn{2}{|c|}{ Possessor } & \multicolumn{2}{|c|}{ Source } & \multicolumn{2}{|c|}{ Dative-like } & \multicolumn{2}{|c|}{ Other } & \multicolumn{2}{|c|}{ Total } \\
\hline & $\mathbf{N}$ & $\%$ & $\mathbf{N}$ & $\%$ & $\mathbf{N}$ & $\%$ & $\mathbf{N}$ & $\%$ & $\mathbf{N}$ & $\%$ & $\mathbf{N}$ & $\%$ \\
\hline Ptol. & 23 & 28 & 42 & $5^{1}$ & 12 & 14 & 2 & 2 & 4 & 5 & 83 & 100 \\
\hline Rom. & 33 & 13 & 121 & 47 & 60 & 23 & 43 & 16 & 3 & 1 & 260 & 100 \\
\hline Byz. & 6 & 15 & 12 & 31 & 12 & 31 & 6 & 15 & 3 & 8 & 39 & 100 \\
\hline
\end{tabular}

The genitive pronoun as subject in a genitive absolute construction shows very few semantic similarities with any dative construction. ${ }^{18}$ Hence it is unlikely that this construction could provide a clear semantic explanation for the merger of these cases. The properties of the possession, source and dative-like genitive constructions, though, appear to be relevant for the functional overlap of the dative and the genitive case and will be analysed in section 5 .

\subsection{Phrasal Genitive Constructions (VG)}

Because both the prenominal genitive (GN) and the phrasal genitive (VG/PG) constructions decrease in relative frequency, the replacement of the dative by the genitive case cannot be found quantitatively in the data shown in table 1. On the other hand, the source and dative-like functions of the genitive in

some of the values are rather small. With 2 degrees of freedom, Cramer's V $=0.20$ should also be considered a small effect size. The standardized residuals show that the results for Ptolemaic-Roman 'GenAbs', Byzantine 'Possessor' and 'Source', Ptolemaic-Roman 'Dativelike' and all in the category 'Other' are contributing most to this chi-square value.

18 The genitive absolute construction consists of a prenominal genitive pronoun following a participle which corresponds to the genitive pronoun in case and number. The pronoun usually takes the role of an agent, e.g. P.Mert. II 65, 6-8 (22.12.118-28.08.119 CE)

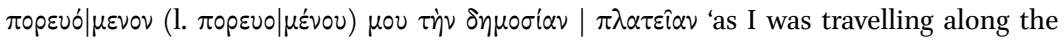
public highway'. Sometimes this role coincides with the role of possessor, cf. P.Ryl. II 116,

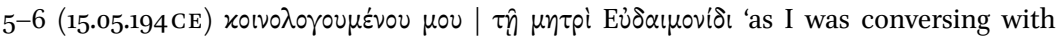
my mother Eudaemonis', although the normal position of the possessor would be post-

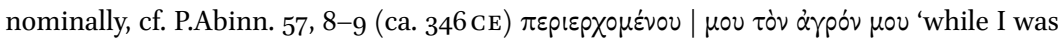
walking around my fields'. Occasionally, the genitive subject is replaced by a dative, see

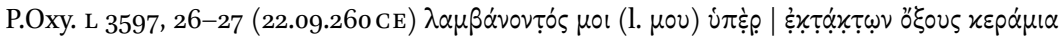

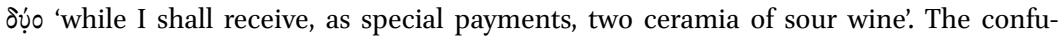
sion can be explained here, as the dative takes the semantic role of a recipient in this phrase. 


\begin{tabular}{lrrrrrrrrrr}
\hline & \multicolumn{4}{c}{ Gen.Abs. } & \multicolumn{4}{c}{ Verb.obj. } & \multicolumn{4}{c}{ Dative-like } & \multicolumn{2}{c}{ Other (PP) } & \multicolumn{2}{c}{ Total } \\
& $\mathbf{N}$ & $\mathbf{\%}$ & $\mathbf{N}$ & $\mathbf{\%}$ & $\mathbf{N}$ & $\mathbf{\%}$ & $\mathbf{N}$ & $\mathbf{\%}$ & $\mathbf{N}$ & $\%$ \\
\hline Ptol. & 133 & 60 & 50 & 23 & 2 & 1 & 35 & 16 & 220 & 100 \\
Rom. & 133 & 39 & 147 & 44 & 16 & 5 & 40 & 12 & 337 & 100 \\
Byz. & 16 & 24 & 8 & 12 & 14 & 21 & 28 & 43 & 68 & 100 \\
\hline
\end{tabular}

prenominal position seem to be increasing (cf. table 2). Also phrasal genitives are found increasingly more often in dative-like functions (see table 3 ) ${ }^{19}$

In the Byzantine period, the dative-like genitive, i.e. the genitive as the recipient-like argument of a ditransitive verb (11), becomes more common than the genitive as direct object $(10){ }^{20}$

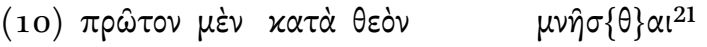 \\ first PRT by god-ACC.SG remind-2SG.AOR.IMP.MID

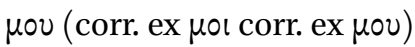 \\ 1SG.GEN \\ 'but first, by god, remind yourself of me' \\ P.Berl.Sarisch 16, 6 (late VI - early VII CE)
}

19 The hypothesis can be rejected that the results in table 3 were generated by chance (Chi-square $=119.5779,6$ degrees of freedom, $\mathrm{p}<2.2 \mathrm{e}-16)$, although caution is required since some of the values are rather small. With 2 degrees of freedom Cramer's v $=0.31$ can be considered a medium effect size. The standardized residuals show that the values in the category Ptolemaic 'Other' and the Roman 'Dative-like' contribute very little to the chi-square value.

20 The phrasal genitive functions in which the genitive pronoun is not positioned adjacent to a noun include the genitive as subject in a genitive absolute construction (Gen.Abs.), cf.

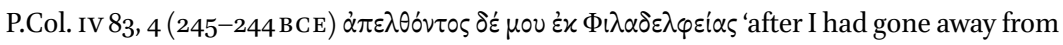
Philadelpheia', as the object argument of a verb construction (Verb.Obj.), cf. (10), or as the recipient-like argument in a ditransitive construction (Dative-like), cf. (11). The remaining constructions gathered in the category 'Other' are predominantly prepositional phrases.

21 Or $\mu \nu \eta \sigma \theta<\hat{\eta} \nu>\nu \alpha$ l, cf. Martin (2003:178). The writer of this papyrus evidently hesitated between the genitive and dative case to denote the object of this verb, hence the scribal corrections of the case form of the pronoun. For the interchange of dative and genitive

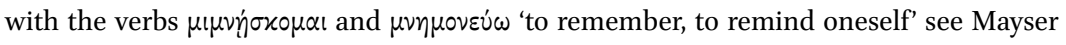
(1934:209-211) and Martin (2003). 


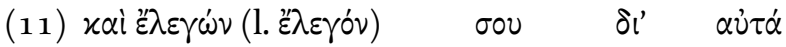
and tell-1SG.IPFV.IND.ACT 2SG.GEN about this-ACC.PL 'and I told you about these things' CPR XV 11, 7 (VICE) ${ }^{22}$

This means that although the prenominal (GN) and postverbal (VG) position became rare for the common genitive possessive pronoun, this position was used increasingly more often for the dative-like functions of the genitive pronoun.

I will take the possessive meaning of the genitive case as starting point for the analysis of the semantics of the genitive pronoun in prenominal position (section 5), before continuing with the extension of the genitive meaning into dative-like semantic roles (section 6).

\section{Semantic Analysis of the Prenominal Genitive}

\subsection{The Genitive as External Possessor}

The possession constructions with a prenominal genitive pronoun in the papyri will be compared with the cross-linguistic distribution of the EPC (cf. section 3.1). This will determine whether the prenominal genitive construction could overlap with the distribution of a dative EPC. The possessum functions in the majority of the results from the papyri as a direct object and hence meets the requirements of the syntactic relations hierarchy (a). ${ }^{23}$ First and second person pronouns are favoured as a possessor in EPCs (b) and the alternation between dative and genitive is also frequently found with personal pronouns (Humbert 1930:166-171; Gianollo 2010:119).

The third feature of EPCs concerns the conceptual domain of the possessum (c). In the gospel of John it seems that all prenominal genitives are found with possessa denoting body parts, personal relationships, personal belongings and

22 The ypsilon of the genitive ending -ov is denoted by a stroke above the line in this text,

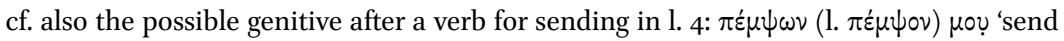
me'.

23 The possessum is occasionally also attested as the subject of a passive verb, e.g. P.Abinn.

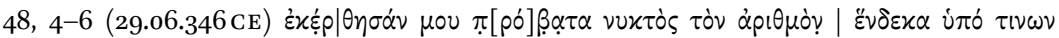

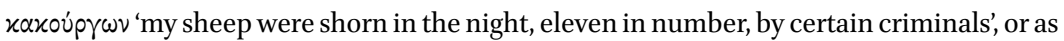
the subject of a transitive verb in a relative clause, e.g. P.Tebt. III.1 799, 11-12 (after 20.08.154

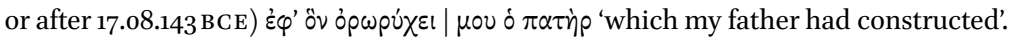


Ptol. Rom. Byz.

Body parts, clothing: foot, clothes

Abstract concepts: reputation, character, rights, problems, name

Kinship relations: father, brother, wife, children

Other human relations: guardian, friend, debtor, lord

Personal possessions: food, mattress, books, possessions

Property: land(s), house, olive grove, estate

Animals: donkey, cows, camels, sheep, pigs

Agricultural products: crops, wheat, wine, trees, artabas

Financial products: drachmas, payment, deposit, rent, investment

Documents: letter(s), ostracon, petition, contract

$\begin{array}{rrr}2 & 5 & 0 \\ 6 & 36 & 4 \\ 6 & 23 & 1 \\ 1 & 7 & 1 \\ & & \\ 6 & 11 & 1 \\ 4 & 17 & 0 \\ 7 & 11 & 0 \\ 3 & 14 & 1 \\ 2 & 13 & 8 \\ 21 & 29 & 9\end{array}$

"intangible entities [...] conceptualized as inalienable possession" (Gianollo 2010:120). In the papyri, however, the possessor and the possessum do not typically occur in a relationship of inalienable possession.

Table 4 shows the conceptual domains of possessa that occur with a prenominal first person possessor in the papyri. Only the nouns that are in a possession relationship with the prenominal genitive pronoun are counted (excluding genitive absolute constructions) and each subcategory is illustrated by several examples of the attested concepts.

The conceptual space of possession contains various subdomains (cf. Stassen 2009:15-25). Two subdomains are distinguished in table 4. The first subdomain covers the possessa often denoted as 'inalienable', i.e. "items that cannot normally be separated from their owners" (Heine 1997:10). The nouns found in this subdomain are items that are inherent to the possessor, such as concrete body parts or clothing, or abstract, intangible entities connected to the identity of the possessor. Because these nouns are always construed in terms of a relation to another entity, they are called relational (Taylor 1996:238-242). Relational nouns often behave differently from non-relational nouns in possessive constructions, as they evoke a certain semantic relation between the possessor and possessum, e.g. 'my mother' always leads to the interpretation of the possessor as a child (Eckhoff 2011:12-19; Barker 2011).

The second subdomain contains alienable items, i.e. items that are nonrelational and separable from their possessors. This notion includes the expression of 'ownership', i.e. only the possessor has the right to make use of the 
possessum or let other people make use of it (Stassen 2009:15-16). Part of the items mentioned in this category might not be possessions owned by the possessor in a strict sense. In the papyri properties such as land for agriculture were often rented out by their legal owner to a tenant and agricultural products could be kept in storage by someone else. In these situations the term 'temporal possession' might be a better one (Stassen 2009:16-17).

Most alienable possessa are concrete items, in contrast to the inalienable possessa which often denote more abstract concepts. Of course, the type of possessum that is attested depends heavily on the type and contents of the texts taken into consideration. The New Testament gospels generally deal with very different topics than the documentary papyri and even within the papyrus documents various text types can be distinguished. ${ }^{24}$ It has been shown by Gianollo (2010:120) that the majority of the extraposed genitives in the Gospel of John express inalienable possessors, but also that the majority of the inalienable possessors occurs in the more common postnominal position. Therefore the distinction between alienable and inalienable possessa does not seem to be a useful criterion to explain the difference between the prenominal and postnominal position of the pronoun. This can be clearly illustrated by comparing the prenominal possessa in the New Testament to the prenominal possessa in the documentary papyri. As the papyri preserve a different type of text with a content that is more concrete than the abstract notions reflected in the Gospel of John, the subdomain of the inalienable possessions is not necessarily the most prominent domain for possessa that occur with prenominal genitive possessors in the papyri (cf. table 4). ${ }^{25}$ Non-relational alienable possessa are very

24 One might be tempted to think that the inalienable possessa occur in private letters and the alienable possessa in contracts and other official documents, but this is not necessarily the case. Most private letters are practical and concerned with (the transfer of) material objects, whereas the expressive narrative of an official petition can provide a valuable source of affected inalienable possessa.

25 A quick search into the placement of the attributive genitive first person singular pronoun in the New Testament, through the Proiel database (Pragmatic Resources in Old IndoEuropean Languages, University of Oslo, http://foni.uio.no:300o), reveals that 412 out of the 633 attestations of $\mu \circ v(65 \%)$ are in postnominal position (NG) and $55(=9 \%)$ are in prenominal position (GN), corroborating the distribution in the papyri in table 1 . The NT distribution would fall in between the distribution of the Ptolemaic ( $42 \% \mathrm{NG} ; 13 \% \mathrm{GN}$ ) and the Roman period ( $70 \% \mathrm{NG} ; 6 \% \mathrm{GN})$, if the uncertain attestations in the papyri are left out. For both the postnominal and prenominal constructions the majority of the possessa are inalienable in the New Testament, resp. $94 \%$ and $87 \%$. This does not support a 
frequent in all periods in the papyri, whereas the inalienable possessa, especially the type of body parts and clothing, are rare among the prenominal possessors (and generally). Therefore the use of inalienable or alienable possessa in prenominal position seems to depend on the type of text rather than on the type of construction. The data from the papyri make it difficult to analyse the prenominal genitive possessor as typical external possessor according to the Inalienability Hierarchy (cf. c, section 3.1).

\subsection{The Affected Possessor}

According to the Situation Hierarchy (d) the EPC is favoured if the possessor is thought of as being (positively or negatively) affected by the circumstances described by the predicate (Fried 1999:486). The role of the affectee differs from the semantic role of a patient, i.e. 'the entity which undergoes the effect of a verbal action', because the effect on the affectee is more abstract, a type of 'mental' affectedness which does not denote a change of state on the participant itself (Fried 1999:488-489; Luraghi 2003:53-54). The affectedness is visible in the extraposed genitive constructions in New Testament Greek (Gianollo 2010:121-123), but also in the prenominal genitive constructions in the papyri.

The degree of affectedness is largely dependent on the nature of the predicate. When the predicate is patient-affecting, such as describing a change of state of the patient, the possessor of the patient is more likely to be affected by the event. Furthermore, the affectedness generated by the verbal predicate is connected to the degree of inalienability of the possessum or the "centrality of the perceived object in the potential target person's personal sphere" (Dąbrowska 1997:16-24). If the possessum is closely related or even inherent to the possessor, e.g. a body part, the possessor is automatically affected by anything concerning the possessum (12). In contrast, if the inalienable possessum is slightly lower on the Inalienability Hierarchy, such as a kinship relation, the affectedness on behalf of the possessor can be assumed but is not obvious (13). In case the predicate itself is non-affecting the affectedness on behalf of the possessor is limited, despite the occurrence of a relational possessum (14).

relation between the inalienability of the possessum and the prenominal position of the possessor. 
(12)

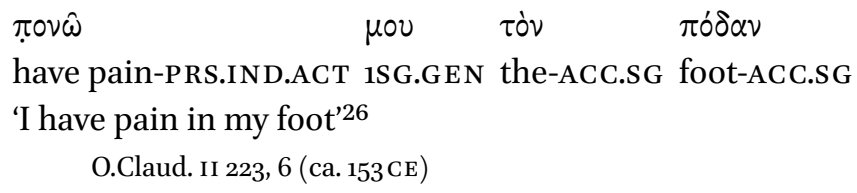

(13)

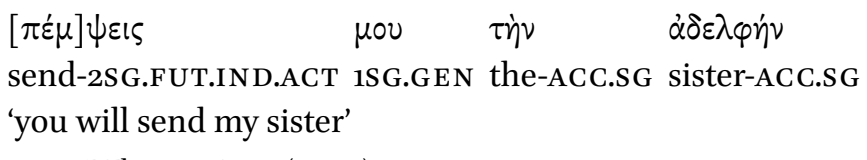

P.Flor. III 365, 10 (III CE)

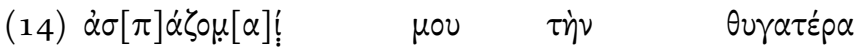 greet-1SG.PRS.IND.MP 1SG.GEN the-ACC.SG daughter-ACC.SG 'I greet my daughter'
P.Hamb. IV 257, 21 (II-III CE)

The combination of the place of the possessum on the inalienability hierarchy together with the place of the verb on the hierarchy of predicate types might determine whether the inalienable genitive pronouns in a prenominal possession construction function as typical external possessors that are directly affected by a patient-affecting predicate.

For the predicate types I adopt the hierarchy from Haspelmath (1999:113) with a further division of the patient-affecting predicate type into verbs expressing a change of state and verbs expressing a change of place (cf. Mitkovska 2011:97; Fried 1999:484). This results in the following hierarchy of predicate types: patient-affecting: change of state < patient-affecting: change of place < dynamic non-affecting < stative. ${ }^{27}$ Table 5 is based only on nouns that are in a possession relationship with the prenominal genitive pronoun, from all three periods (cf. table 4$) \cdot{ }^{28}$

26 The pain was inflicted here by a scorpion bite. Unlike the event of the bite itself (in l. 5 of the same text), the verb $\pi \circ v \hat{\omega}$ is stative and not patient-affecting. Because the possessum is inalienable and the possessor is identical to the experiencer, the possessor is affected by the experience.

27 See also the affectedness scale based on parameters to classify verbal actions sketched in Riaño 2014:525-526, n. 11.

28 The category 'Other' contains the examples in which the possessum is not the object argument of the preceding predicate, but the subject of a non-copular verb. This occurs sometimes in relative clauses or with passive verbs, cf. n. 23 and e.g. P.Petr. II $19.26-7$

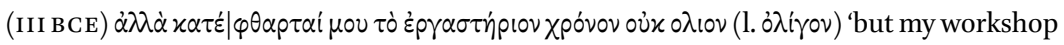
has been unemployed for a long time' (for the translation see P.Ent., p. 77); but also 
TABLE 5 Predicate type vs. alienability possessum in prenominal genitive possession constructions

\section{Change of state Change of place Dynamic Stative Other}

\begin{tabular}{lrlllr} 
Inalienable & 4 & 10 & 14 & 58 & 11 \\
Alienable & 16 & 73 & 20 & 33 & 6 \\
\hline
\end{tabular}

Inalienable possessa are limited in the Ptolemaic and Byzantine period for all predicate types. The Roman period preserves more examples of inalienable possessors, especially with stative verbs $\left(5^{1 \times}\right) .{ }^{29}$ The Greek papyri from all three periods preserve the highest amount of prenominal possessors with patient-affecting (change of place) predicates and alienable possessa. ${ }^{30}$ Part of the explanation of this distribution might lie in the nature of the documentary papyri that happen to contain many references to the transfer of documents and other alienable objects.

Cross-linguistically, EPCs are favored in constructions featuring a patientaffecting predicate and an inalienable possessum. In the possession constructions featuring a prenominal genitive possessive pronoun, however, the patient-affecting predicates are found with alienable possessa, whereas the inalienable possessa mainly occur with non-affecting predicates. ${ }^{31}$ Therefore, I

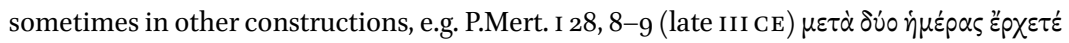

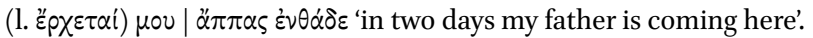

29 Examples of the inalienable possessum with a change of place, dynamic and stative predicate are given in examples (12)-(14). Another example of a stative verb with an

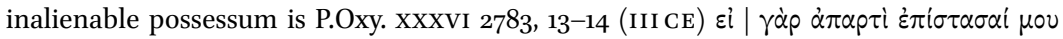
$\tau \grave{\eta} \nu \gamma(\omega) \mu \eta \nu$ 'for if you (want to) know my opinion just now'. One of the rare examples of a predicate affecting the state of an inalienable possessum can be found in SB XVI 12671, 4-5

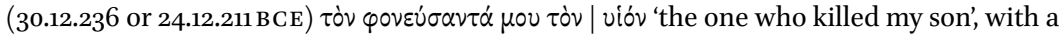
special note by the editors on the word order (ed.pr., n. to l. 4-5): "emotional erscheint die

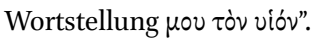

3o Examples of affecting predicates (change of state and change of place) in combination with an alienable possessum will be discussed in 5.3 and 5.4. An example of an alienable possessum as the object of a dynamic verb can be found in P.Flor. II 248, 15-16

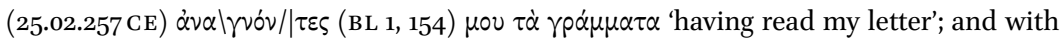

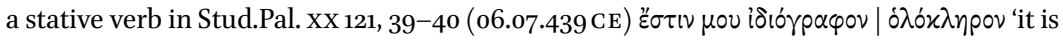
my autograph entirely'.

31 A Fisher's exact test taking the total of the patient-affecting predicates (change of state and change of place) vs. the non-patient-affected predicates (dynamic and stative) results in $\mathrm{p}$ 
conclude that the prenominal genitive construction in the papyri does not function as typical external possession construction. Even though the prenominal possessor cannot be identified with an external possessor in the Greek papyri, this does not exclude the possibility that the external possession construction was involved in the interchange of the dative and the genitive cases at other stages in the development of the Greek language. As far as the Greek language of the papyri is concerned, another path of extension of the genitive case might be more likely.

\subsection{Affectedness and Alienable Possessors}

Since prenominal genitives do not function as external possessors in the Greek papyri, the reanalysis of the prenominal genitive as a dative in an external possession construction cannot provide a sufficient explanation for the merger of the genitive and the dative case in Greek based on papyrus documents. Even though the prenominal genitives are usually not inalienable possessors that are directly affected by the event expressed by the predicate, this does not mean that affected possessors are not found in the papyri at all. For instance, the variation in case marking in the Greek language depends to a large extent on the lexical semantics of the verb and the affectedness of the object (Riaño 2014). The patient-affecting predicates that are constructed with alienable possessa also generate affectedness on behalf of the possessor, see (15) and (16).

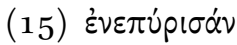

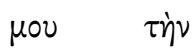
$\ddot{\alpha} \omega \omega$
burn-3P L.AOR.IND.ACT 1SG.GEN the-ACC.SG threshing.floor-ACC.SG 'they set my threshing floor on fire'
P.Petr. II 34a, 5-6 (210-183 в CE; BL 9, 210)

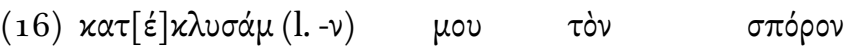
flood-3PL.AOR.IND.ACT 1SG.GEN the-ACC.SG seed-ACC.SG 'they flooded my seeds'
P.Ent. 6o, 4 (13.01.218 BCE)

The difference between affectedness with an inalienable possessor and an alienable possessor can be explained by the event structure according to the theory called 'flow of affectedness' (Marantz 1993). The affecting of an inalienable possessor occurs within the same event as the affecting of the patient/pos-

$=2.996 \mathrm{e}-08$, which suggests that the distribution of the alienable and inalienable possessa is significant here. 
sessum, while the affecting of an alienable possessor or benefactive/malefactive involves an event sequentially following the event affecting the patient/ possessum (Marantz 1993:144). The role of the possessor in an alienable possession construction is therefore highly similar to the role of a benefactive/malefactive or the recipient-like argument of a ditransitive construction (Alexiadou 2003:184n.10). Affectedness seems to be a useful criterion to characterize the prenominal possession construction in the papyri. ${ }^{32}$

\subsection{Other Genitive Affectees}

Before moving on to the semantic extension of the genitive as an alienable possessor to the role of benefactive or goal, there is one more observation to be made concerning the prenominal genitive. The affectedness of an alienable possessor or a benefactive goal is remarkably similar to the affectedness of a malefactive source. The animate source of separation 'the entity from which something moves' coincides with the role of malefactive with verbs for 'taking' or 'stealing. When the postverbal position of the genitive pronoun denoting the malefactive source (17) coincides with the prenominal position of a genitive pronoun, the malefactive source can also be interpreted as a possessor, $\mathrm{cf}$. $(18)-(19) \cdot{ }^{33}$

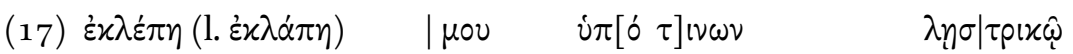
steal-3SG.AOR.IND.PASS 1SG.GEN by someone-GEN.PL thievish-DAT.SG

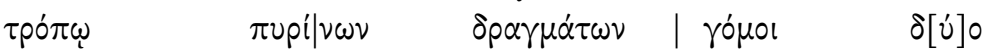
manner-DAT.SG wheat-GEN.PL sheave-GEN.PL load-NOM.PL two 'there were thievishly stolen from me by certain individuals two loads of wheat-sheaves'

P.Ryl. II 137, 11-15 (27.05.-24.06.34 CE)

32 Similar examples of prenominal alienable possessors with patient-affecting predicates can be found in the Gospel of Luke, cf. Luke 12.18: $x \alpha \theta \varepsilon \lambda \hat{\omega} \mu \circ \nu \tau \dot{\alpha} \varsigma \dot{\alpha} \pi \circ \theta \dot{\eta} x \alpha \varsigma^{\prime}$ 'I will pull down

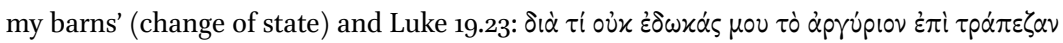
'why did you not give my money to the bank' (change of place).

33 Among the examples of malefactive source constructions the object of stealing is sometimes expressed with a definite article (19) and sometimes without the article (18). The lack of the definite article might point to the source interpretation and the presence of the article to the possessive interpretation of the genitive pronoun. But even without complete ambiguity between the two roles, the overlap in the position and meaning of both genitive pronouns is inevitable. 
(18) $\dot{x} x \lambda \varepsilon^{\prime} \pi \eta\left(1 . \varepsilon^{\prime} x \lambda \dot{\alpha} \pi \eta\right) \quad \mu 0 v \quad \delta \dot{\varepsilon} \lambda \varphi \alpha \xi \mid$

steal-3SG.AOR.IND.PASS 1SG.GEN young.pig-NOM.SG

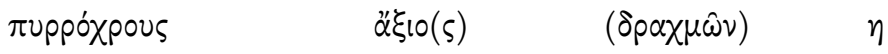

tawny.coloured-NOM.SG worth-NOM.SG drachma-GEN.PL 8

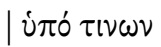

by some-GEN.PL

'there was stolen from me a young tawny-coloured pig worth eight drachmas by certain individuals'

P.Ryl. II 140, 11-14 (15-26.11.36 CE)

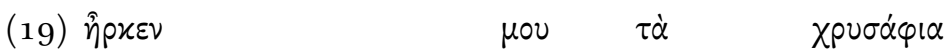

take.away-3SG.PRF.IND.ACT 1SG.GEN the-ACC.PL money-ACC.PL

'she (sc. my daughter) took away my mon'

SB XVI 12326, 8 (late III CE)

The first event expressed by the verbal predicate deprives the alienable possessor of his property and consequently the possessor is also mentally or emotionally affected by the event. Most examples of prenominal genitive pronouns expressing a malefactive source are therefore affected possessors, just as the other examples of alienable genitive possession constructions. This specialised possessive meaning of the genitive could have provided a basis for the extension into dative roles such as benefactive and goal.

\section{Semantic Extension of the Genitive Case}

\subsection{Genitive as Benefactive and Goal}

The semantic ambiguity between the genitive as possessor and the genitive as malefactive can be observed from the genitive source constructions (5.4). The same overlap can also be found in theme benefactive constructions, compare for example the dative benefactive pronoun in (20) and the genitive possessor or benefactive in (1), repeated below as (21).

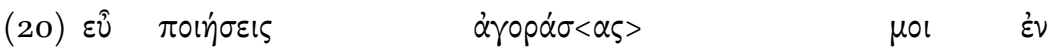
well do-2SG.FUT.IND.ACT buy-AOR.PTCP.ACT.NOM.SG 1SG.DAT in

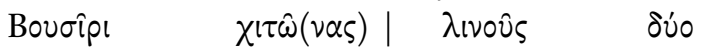

Busiris-DAT.sG tunic-ACC.PL linen-ACC.PL two 'it would be nice if you could buy for me in Bousiris two linen tunics' P.Oslo II 56, 3-4 (II CE) 


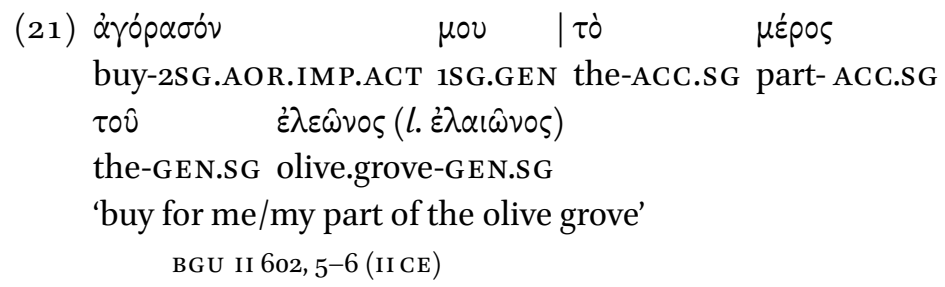

Furthermore, the same type of overlap of semantic roles can be found between the genitive as possessor and goal (cf. Markopoulos 2010:123). The semantic role of goal is understood here as 'the entity towards which another entity moves'. The movement towards the goal is typically expressed by verbs like 'bring' or 'send', compare the dative as goal argument in (22) to the ambiguous position of the genitive as possessor and goal in (23) and the genitive as goal in (24).

(22) $\delta$ òs

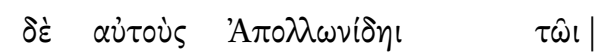

give-2SG.AOR.IMP.ACT and 3PL.ACC Apollonides-DAT.SG the-DAT.SG

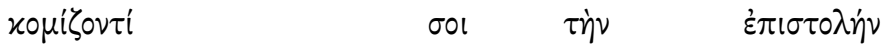

bring-PRS.PTCP.ACT.DAT.SG 2SG.DAT the-ACC.SG letter-ACC.SG 'give them to Apollonides who brings you the letter'

P.Mich. I 22, 6-7 (29.07.257 BCE)

(23) dòs

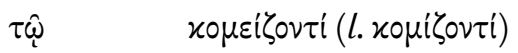

give-2SG.AOR.IMP.ACT the-DAT.SG bring-PRS.PTCP.ACT.DAT.SG

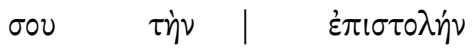

2SG.GEN the-ACc.sG letter-ACC.SG

'give to the one who brings to you the letter (= your letter)'34

P.OXy. II $296,3^{-4}(24.03 .37$ or 41 or 55 CE)

(24) $\dot{\alpha} \pi \hat{\varepsilon} \sigma \tilde{\sigma}[\tau] \varepsilon ! \lambda \lambda \dot{\alpha}$

боv $\tau \alpha \dot{\delta} \varepsilon$

$\dot{\varepsilon} \pi เ \sigma \mid[\tau o ́ \lambda ı \alpha$

send-1SG.AOR.IND.ACT 2SG.GEN this-ACC.PL letter-ACC.PL

'I sent you these letters'35

P.Mich. VIII 517, 6-7 (III-IVCE)

34 The genitive pronoun was corrected by the editors into the expected dative pronoun, presumably based on parallel texts such as (22).

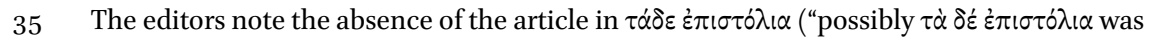
intended") and the usage of the genitive instead of the expected dative pronoun; see ed.pr. n. to l. 6 and $6-7$. 
In these examples (23-24) the goal argument expressed by the genitive pronoun can be interpreted as the prospective possessor of the letters. The semantic extension of the genitive case into goal-oriented semantic roles of benefactive or goal can be motivated by the semantic extension from possessor to prospective possessor (Pompeo and Benvenuto 2011:113; Pompeo 2012:539).

\subsection{The Final Stage of Semantic Extension}

The final stage of semantic extension of the genitive case into dative semantic roles would involve the use of a genitive as verbal complement without a following noun that might function as the possessum. The cases in which the genitive takes a dative function without any potential possessive meaning can be found among the results of table 3 , the dative-like non-possessive genitive pronouns that are not adjacent to a noun (VG). Apart from the roles of benefactive and goal, the non-possessive genitive pronoun is found in the roles of addressee (25), cf. also example (11), and recipient (26).

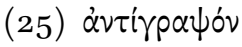

xai

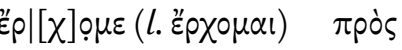

write-2SG.AOR.IMP.ACT 1SG.GEN and come-1SG.PRS.IND.MP to

$\sigma \alpha i(l . \sigma \dot{\varepsilon})$

2SG.ACC

'write back to me and I come to you'

P.Lund. II 5, 18-19 (ca. 500 CE)

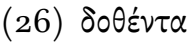

Hov

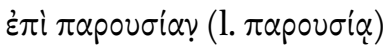

give-AOR.PTCP.PASS.ACC.PL 1SG.GEN in presence-ACC.SG

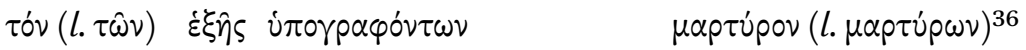

the-GEN.PL next sign-PRS.PTCP.ACT.GEN.PL witness-GEN.PL

'(sc. the money) given to me in the presence of the undersigned witnesses'

P.Dubl. 32, 17 (07.09.512 CE)

36 There are more problems with the interpretation of the case forms in this phrase, cf.

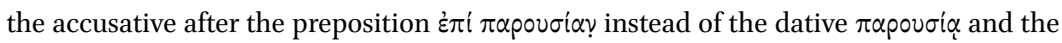

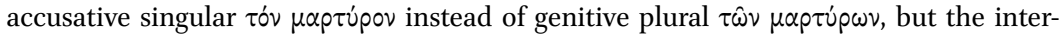
change of $\omega-0$ and the addition of final /n/ can be explained by changes in the pronunciation in the Byzantine period (Gignac 1976:112-114; 275-277). The apparent interchange between the neuter accusative plural participle $\delta 0 \theta \varepsilon \dot{v} \tau \alpha(26$, H. 2) and the masculine accusative plural $\delta 0 \theta \varepsilon v \tau \dot{\alpha} \varsigma$ (same text, l. 8, H. 1) might be based on different choices in nominal agreement by the scribes. For the increasing employment of 'uninflected' participles in -ov $\alpha$ see Manolessou 2005. 
A recipient is the third argument of verbs of 'giving'. These verbs involve a transfer of one entity to another entity, the recipient, which functions as the endpoint of the transfer. An addressee is the endpoint of verbs of 'saying' or 'writing'. The communication is then conceived as a physical motion towards the addressee (Luraghi 2003:39). Hence the dative semantic roles that are taken over by the genitive case all describe an endpoint (goal-oriented) movement and most of them are indirectly affected by a patient-affecting (change of place) verbal predicate.

The examples in which the genitive pronoun can ambiguously be interpreted as possessor and benefactive or goal are predominantly attested between the first and the third century $\mathrm{CE}$, whereas the majority of the examples in which the genitive is used in a dative role without the possibility of a possessive interpretation are found in the late Roman and Byzantine period. Although this distribution suggests a chronological development, it is speculative given the limited amount of evidence to determine the exact stages of diachronic semantic extension through this continuum of dative semantic roles. Additional research both cross-linguistically and regarding other sources for the Greek language might reveal the most likely path of semantic extension taken by the genitive into the various goal-oriented roles commonly expressed by the dative case in Greek.

\section{7}

\section{Conclusion}

In this article I examined the interchange between the dative and the genitive case in first person singular pronouns in Greek papyri. During the Ptolemaic, Roman and Byzantine periods, variation between postnominal and prenominal position of the genitive possessive pronoun is disappearing. The pragmatically governed variation in word order within the noun phrase is replaced by a fixed postnominal position of the possessive pronoun. While the relative frequencies of the genitive pronoun in prenominal position and as a verbal complement are decreasing, the genitive pronouns that are still attested in those constructions seem to be used more often in former dative semantic roles.

Previous studies have shown that the syntactic overlap between dative and genitive cases is often found in the postverbal position of the dative pronoun and the prenominal position of the genitive pronoun. The thesis is defended here that semantic extension of the prenominal genitive pronoun might provide an explanation for the start of the merger of the genitive and dative cases. The prenominal genitive pronoun in the papyri is typically found between a 
verbal form and an alienable possessum which functions as the patient of the predicate. When the event expressed by the predicate is patient-affecting, the alienable possessor is indirectly also affected. Hence the semantic role of this affected alienable possessor might ambiguously be interpreted as a benefactive/malefactive in common genitive possession constructions. In the Roman period the prenominal genitive pronoun can also be found in the roles of possessor and goal which can be understood as a semantic extension from possessor to prospective possessor. From the fourth century CE onwards the meaning of the genitive pronoun is also extended into other goal-oriented roles commonly expressed by the dative case, such as addressee and recipient.

Further study of the stages of this case alternation is needed, for instance of the replacement of the dative by the genitive with nominal forms and other pronouns than the first person singular clitic pronoun. Apart from the genitive case, also the accusative case can be used as a replacement for the goal-oriented roles of the dative case. Future research into New Testament Greek, Greek inscriptions and other (contemporary) sources for Greek language might reveal further explanations for these developments in the case system and will allow us to put the results found in the papyri into perspective.

\section{References}

Alexiadou, Artemis. 2003. "Some notes on the structure of alienable and inalienable possessors". In From NP to DP Volume II: The Expression of Possession in Noun Phrases, Martine Coene and Yves D'Hulst (eds.), 167-188. Amsterdam: John Benjamins.

Bagnall, Roger S. and Raffaella Cribiore. 2006. Women's Letters from Ancient Egypt, $300 B C-A D 800$. Michigan: University of Michigan Press.

Barðdal, Jóhanna and Leonid Kulikov. 2009. "Case in decline". In The Oxford Handbook of Case, Andrej Malchukov and Andrew Spencer (eds.), 470-478. Oxford: Oxford University Press.

Barker, Chris. 2011. "Possessives and relational nouns". In Semantics: An international handbook of natural language meaning, Klaus von Heusinger, Claudia Maienborn, \& Paul Portner (eds.), 1009-1130. Berlin: Mouton de Gruyter.

Benvenuto, Maria Carmela and Flavia Pompeo. 2012. "Expressions of predicative pos-

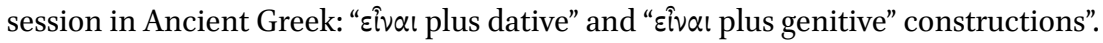
AION Sezione Linguistica 1, 77-103.

Breuillot, Martine. 1997. "La place des pronoms personnels au génitif: point de vue diachronique". Cahiers Balkaniques 26, 61-71.

Browning, Robert 1983. Medieval and Modern Greek. Cambridge: Cambridge University Press. 
Bubeník, Vít. 1989. Hellenistic and Roman Greece as a Sociolinguistic Area. Amsterdam: John Benjamins.

Clackson, James. 2007. Indo-European Linguistics: An Introduction. Cambridge: Cambridge University Press.

Cooper, Adam and Effi Georgala. 2012. "Dative loss and its replacement in the history of Greek". In Historical Linguistics 2009. Selected Papers from the 19th International Conference on Historical Linguistics, Nijmegen, 10-14 August 2009, Ans M.C. van Kemmenade and Nynke de Haas (eds.), 277-292. Amsterdam: John Benjamins.

Dabrowska, Ewa. 1997. Cognitive semantics and the Polish dative [Cognitive linguistics research 9]. Berlin: Mouton de Gruyter.

Dieterich, Karl. 1898. Untersuchungen zur Geschichte der griechischen Sprache von der hellenistischen Zeit bis zum 10. Jahrhundert n.Chr. Leipzig: Teubner.

Eckhoff, Hanne Martine. 2011. Old Russian Possessive Constructions. A Construction Grammar Approach. Berlin: Mouton de Gruyter.

Evans, Trevor V. and Dirk D. Obbink. 2010. "Introduction". In The Language of the Papyri, Trevor V. Evans and Dirk D. Obbink (eds.), 1-12. Oxford: Oxford University Press.

Fried, Mirjam. 1999. "From Interest to Ownership: a Constructional View of External Possessors". Payne and Barshi 1999, 473-504.

Gianollo, Chiara. 2010. "External possession in New Testament Greek". In Papers on grammar XI, Gualtiero Calboli and Pierluigi Cuzzolin (eds.), 101-129. Roma: Herder Editrice. [Republished in Journal of Latin Linguistics 11.1 (2010) 101-130]

Gignac, Francis Thomas. 1976. A Grammar of the Greek Papyri of the Roman and Byzantine Periods. Volume I: Phonology. Milano: La Goliardica.

Gignac, Francis Thomas. 1981. A Grammar of the Greek Papyri of the Roman and Byzantine Periods. Volume II: Morphology. Milano: La Goliardica.

Haspelmath, Martin. 1999. "External Possession in a European Areal Perspective". In Payne and Barshi 1999, 109-135.

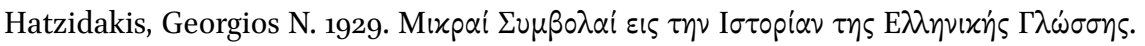
Athēna 41, 3-24.

Havers, Wilhelm.1911. Untersuchungen zur Kasussyntax der indoeuropäischen Sprachen. Strassburg: Trübner.

Heine, Bernd. 1997. Possession. Cognitive sources, forces, and grammaticalization. Cambridge: Cambridge University Press.

Horrocks, Geoffrey 2007. "Syntax: From Classical Greek to the Koine". A History of Ancient Greek. In From the Beginnings to Late Antiquity, A.-F. Christides (ed.), 618631. Cambridge: Cambridge University Press.

Horrocks, Geoffrey. 2010. Greek: A History of the Language and its Speakers. Second Edition. Malden, MA: Wiley-Blackwell.

Humbert, Jean. 1930. La disparition du datif en grec (du I ${ }^{e r}$ au $X^{e}$ siècle). Paris: Édouard Champion. 
Jannaris, A.N. 1897. An Historical Greek Grammar. London: Macmillan.

Janse, Mark. 1993. "La position des pronoms personnels enclitiques en grec néo-testamentaire à la lumière des dialectes néo-helléniques". In La koiné grecque antique I, Claude Brixhe (ed.), 83-121. Nancy: Presses Universitaires de Nancy.

Janse, Mark. 2002. "Aspects of Bilingualism in the History of the Greek language". In Bilingualism in Ancient Society: Language Contact and the Written Word, James N. Adams, Mark Janse and Simon Swain (eds.), 332-39o. Oxford: Oxford University Press.

Kapsomenakis, Stylianos G. 1938. Voruntersuchungen zu einer Grammatik der Papyri der nachchristlichen Zeit. Münchener Beiträge zur Papyrusforschung und antiken Rechtsgeschichte 28 .

Kittilä, Seppo and Fernando Zúñiga. 2010. "Introduction. Benefaction and malefaction from a cross-linguistic perspective". In Benefactives and Malefactives. Typological perspectives and case studies, Fernando Zúñiga and Seppo Kittilä (eds.), 1-28. Amsterdam: John Benjamins.

König, Ekkehard and Martin Haspelmath. 1998. "Les constructions à possesseur externe dans les langues d'Europe". In Actance et Valence dans les Langues d'Europe, Jack Feuillet (ed.), 525-6o6. Berlin: Mouton de Gruyter.

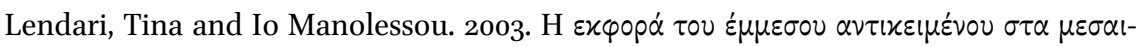

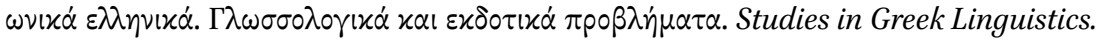
Proceedings of the 23nd [sic] Annual Meeting of the Department of Linguistics, 17-19 May 2002, 394-405. Aristotle University of Thessaloniki.

Luraghi, Silvia. 2003. On the Meaning of Prepositions and Cases. The expression of semantic roles in Ancient Greek. Amsterdam: John Benjamins.

Malchukov, Andrej, Martin Haspelmath and Bernard Comrie. 2010. "Ditransitive constructions: a typological overview”. In Studies in Ditransitive Constructions: A Comparative Handbook, Andrej Malchukov, Martin Haspelmath and Bernard Comrie (eds.), 1-64. Berlin: Mouton de Gruyter.

Manolessou, Io. 2005. "From participles to gerunds". In Advances in Greek Generative Syntax: In honor of Dimitra Theophanopoulou-Kontou, Melita Stavrou and Arhonto Terzi (eds.), 241-283. Amsterdam: John Benjamins.

Marantz, Alec. 1993. "Implications of Asymmetries in Double Object Constructions". In Theoretical Aspects of Bantu Grammar 1, Sam A. Mchombo (ed.), 113-150. Stanford: CSLI Publications.

Markopoulos, Theodore. 2010. "Case overlap in Medieval Cypriot Greek. A socio-historical perspective". Folia Linguistica Historica 31, 89-134.

Martin, Alain. 2003. "'Souviens-toi de moi dans tes saintes prières'. Témoins tardifs de la vitalité du datif grec”. Zeitschrift fur Papyrologie und Epigraphik 144, 177-180.

Mayser, Edwin. 1934. Grammatik der griechischen Papyri aus der Ptolemäerzeit. II.2 Satzlehre, Analytischer Teil 2. Berlin \& Leipzig: Walter de Gruyter. 
Merlier, Octave 1931. "Le remplacement du datif par le génitif en grec moderne”. Bulletin de Correspondance hellénique 55, 207-228.

Mitkovska, Liljana. 2011. "Competition between Nominal Possessive Constructions and the Possessive Dative in Macedonian". In The Grammar of Possessivity in South Slavic Languages: Synchronic and Diachronic Perspectives (Slavic Eurasian Studies 24), Motoki Nomachi (ed.), 83-109. Sapporo: Slavic Research Centre, Hokkaido University.

Newman, John. 1996. Give: A Cognitive Linguistic Study. Berlin: Mouton de Gruyter.

Nikiforidou, Kiki. 1991. "The meanings of the genitive: A case study in semantic structure and semantic change". Cognitive Linguistics 2:2, 149-205.

Payne, Doris L. and Immanuel Barshi. 1999. External Possession. Amsterdam: John Benjamins.

Pompeo, Flavia and Maria Carmela Benvenuto. 2011. "Il genitive in persiano antico. Un caso esemplare di categoria polisemica". Studi e saggi linguistici 49, 75-123.

Pompeo, Flavia. 2012. "Il sincretismo di genitivo e dativo nella lega balcanica. Una convergenza multipla?". Studi Italiani di Linguistica Teorica e Applicata 41:3, 531-544.

Riaño Rufilanchas, Daniel. 2014. "Differential Object Marking in Ancient Greek". Linguistics 52.2, 513-541.

Stassen, Leon. 2009. Predicative Possession. Oxford: Oxford University Press.

Taylor, Ann. 2002. "The Distribution of Object Clitics in Koiné Greek”. In Indo-European Perspectives (Journal of Indo-European Studies Monograph 43), Mark Southern (ed.), $285^{-315}$.

Taylor, John R. 1996. Possessives in English: An Exploration in Cognitive Grammar. Oxford: Oxford University Press.

Torallas Tovar, Sofia. 2010. "Greek in Egypt". In A Companion to the Ancient Greek Language, Egbert J. Bakker (ed.), 253-266. Oxford: Wiley-Blackwell.

Trapp, Erich. 1965. "Der Dativ und der Ersatz seiner Functionen in der byzantinischen Vulgärdichtung bis zur Mitte des 15. Jahrhunderts". Jahrbuch der Österreichischen Byzantinistik 14, 21-34. 